\title{
Efforts to Prevent Surgical Site Infection After Colorectal Surgery
}

\author{
Byung Wook Min \\ Division of Colorectal Surgery, Department of Surgery, Korea University Guro Hospital, Korea University College of Medicine, Seoul, Korea
}

See Article on Page 235-242

A surgical-site infection (SSI) is one of the most interesting issues among surgeons and is the second most frequent nosocomial infection (20\%) after urinary tract infection (36\%) [1]. The severity of a SSI can vary from trivial to very significant as it can be highly associated with morbidity and mortality. It can also increase the clinical and financial burden because affected patients will need to undergo longer hospitalizations [2].

The causes of SSIs have been considered to be related to three factors: the patient, the contaminating organisms, and the operative procedure [3-5]. The patient-related factors, the most important factors in the development of SSIs [6], include old age, immunocompromised condition, and comorbidity such as cirrhosis, diabetes, chronic obstructive pulmonary disease, and cancer [3, 5-8]. The contaminating organisms isolated from SSIs are expected to have originated from the patient's endogenous flora. They will be polymicrobial if the procedure involves opening the colon or rectum [3]. The procedure-related factors consist of inadequate skin preparation, poor preoperative shaving, a long duration of surgery, inadequate ventilation of the operating room, and massive tissue trauma $[3,5,7,9-11]$.

In colorectal surgery, surgeons especially give more attention to taking care of the surgical site to avoid infection because wounds of opened viscus organs, such as the colon and the rectum, are considered a clean-contaminated wound, even though the surgery is performed without contamination. A clean wound, in general, is not related with a SSI. Furthermore, fecal contamina-

Correspondence to: Byung Wook Min, M.D.

Division of Colorectal Surgery, Department of Surgery, Korea University Guro Hospital, Korea University College of Medicine, 148 Gurodong-ro, Guro-gu, Seoul 08308, Korea

Tel: +82-2-2626-3079, Fax: +82-2-2626-1148

E-mail: gsmin@korea.ac.kr

(C) 2015 The Korean Society of Coloproctology

This is an open-access article distributed under the terms of the Creative Commons Attribution NonCommercial License (http://creativecommons.org/licenses/by-nc/3.0) which permits unrestricted noncommercial use, distribution, and reproduction in any medium, provided the original work is properly cited. tion and bacterial translocation during the colorectal surgery can cause a postoperative infection and increase the morbidity and mortality.

These unpleasant SSIs can be prevented by using several processes, including preoperative skin antisepsis, maintenance of normothermia during surgery, appropriate hair removal, use of a wound protector, and administration of prophylactic antibiotics (PAs). Particularly, in colorectal surgery, the traditional regimens to prevent SSIs are prolonged fasting, bowel preparation, and antibiotic prophylaxis.

Because PAs have reduced the incidence of SSIs in colorectal surgery, the colon surgery guidelines recommend that PAs be administered perioperatively [12]. The U.S. Food and Drug Administration approved second-generation cephalosporin monotherapy or a combination of first-generation cephalosporin with metronidazole or ampicillin-sulbactam as PAs for colorectal surgery. However, although previous studies recommended that the duration of prophylaxis be within 24 hours after surgery and showed that long-term prophylaxis was not useful for reducing the wound infection rate $[13,14]$, the current practices in Korea tend to administer different combinations and to use different durations of PAs in different hospitals [15]. The abuse of antibiotics is well known to increase resistance to the antibiotic; in fact, the number of SSIs caused by antibiotic-resistant bacteria and fungi is on the rise $[3,11,16,17]$, which is the reason continuous research for preventing SSIs has been emphasized.

For better results, a national consensus for SSI prevention should be reached at the government level in Korea. The American College of Surgeons National Surgical Quality Improvement Program is a national program in the United States to measure surgical outcomes in order to improve surgical care. It has constructed a surgery-related database that has been nationally validated [18]. In Korea, the Korean Nosocomial Infections Surveillance System (KONIS) was established in 2006 [19]. This system uses the KONIS Web-based Reporting and Analysis Program provided by voluntary participation of hospitals for the collection and sharing of SSI data. Recently, KONIS has tried to involve more hospitals and to make a qualified database. This continuous effort is instrumental if the incidence rate of SSIs is to be decreased, which 
would also decrease the financial burden of health care and increase the quality of surgical outcomes.

\section{CONFLICT OF INTEREST}

No potential conflict of interest relevant to this article was reported.

\section{REFERENCES}

1. Klevens RM, Edwards JR, Richards CL Jr, Horan TC, Gaynes RP, Pollock DA, et al. Estimating health care-associated infections and deaths in U.S. hospitals, 2002. Public Health Rep 2007;122: 160-6.

2. Vegas AA, Jodra VM, Garcia ML. Nosocomial infection in surgery wards: a controlled study of increased duration of hospital stays and direct cost of hospitalization. Eur J Epidemiol 1993;9: 4-10.

3. Mangram AJ, Horan TC, Pearson ML, Silver LC, Jarvis WR. Guideline for prevention of surgical site infection, 1999. Hospital Infection Control Practices Advisory Committee. Infect Control Hosp Epidemiol 1999;20:250-78.

4. Toles A. Artificial nails: are they putting patients at risk? A review of the research. J Pediatr Oncol Nurs 2002;19:164-71.

5. Kirby JP, Mazuski JE. Prevention of surgical site infection. Surg Clin North Am 2009;89:365-89.

6. Dominioni L, Imperatori A, Rotolo N, Rovera F. Risk factors for surgical infections. Surg Infect (Larchmt) 2006;7 Suppl 2:S9-12.

7. Owens CD, Stoessel K. Surgical site infections: epidemiology, microbiology and prevention. J Hosp Infect 2008;70 Suppl 2:3-10.

8. Anderson DJ, Kaye KS, Classen D, Arias KM, Podgorny K, Burstin $\mathrm{H}$, et al. Strategies to prevent surgical site infections in acute care hospitals. Infect Control Hosp Epidemiol 2008;29 Suppl 1:S51-61.

9. Jensen LS, Andersen A, Fristrup SC, Holme JB, Hvid HM, Kraglund $\mathrm{K}$, et al. Comparison of one dose versus three doses of prophylactic antibiotics, and the influence of blood transfusion, on infectious complications in acute and elective colorectal surgery. Br J Surg 1990;77:513-8.

10. Cuthbertson AM, McLeish AR, Penfold JC, Ross H. A comparison between single and double dose intravenous Timentin for the prophylaxis of wound infection in elective colorectal surgery. Dis Colon Rectum 1991;34:151-5.

11. Stein GE. Antimicrobial resistance in the hospital setting: impact, trends, and infection control measures. Pharmacotherapy 2005; 25(10 Pt 2):44S-54S.

12. Townsend CM Jr, Beauchamp RD, Evers BM, Mattox KL. Sabiston textbook of surgery: the biological basis of modern surgical practice. 19th ed. Philadelphia: Elservier Saunders; 2012.

13. Nelson RL, Glenny AM, Song F. Antimicrobial prophylaxis for colorectal surgery. Cochrane Database Syst Rev 2009;(1):CD001181.

14. Park YY, Kim CW, Park SJ, Lee KY, Lee JJ, Lee HO, et al. Influence of shorter duration of prophylactic antibiotic use on the incidence of surgical site infection following colorectal cancer surgery. Ann Coloproctol 2015;31:235-42.

15. Jeong WK, Park JW, Lim SB, Choi HS, Jeong SY. Cefotetan versus conventional triple antibiotic prophylaxis in elective colorectal cancer surgery. J Korean Med Sci 2010;25:429-34.

16. Sydnor ER, Perl TM. Hospital epidemiology and infection control in acute-care settings. Clin Microbiol Rev 2011;24:141-73.

17. Nguyen GC, Leung W, Weizman AV. Increased risk of vancomycin-resistant enterococcus (VRE) infection among patients hospitalized for inflammatory bowel disease in the United States. Inflamm Bowel Dis 2011;17:1338-42.

18. Jones RS, Brown C, Opelka F. Surgeon compensation: "Pay for performance," the American College of Surgeons National Surgical Quality Improvement Program, the Surgical Care Improvement Program, and other considerations. Surgery 2005;138:829-36.

19. Kim ES, Kim HB, Song KH, Kim YK, Kim HH, Jin HY, et al. Prospective nationwide surveillance of surgical site infections after gastric surgery and risk factor analysis in the Korean Nosocomial Infections Surveillance System (KONIS). Infect Control Hosp Epidemiol 2012;33:572-80. 